\title{
THE ANALYSIS OF ECONOMIC ACTIVITIES OF WASTE RECYCLING SCAVENGERS IN TERJUN URBAN VILLAGE MEDAN MARELAN SUB-DISTRICT
}

\author{
Ashri Maulida $\left.{ }^{1 *}\right)$, Arwansyah ${ }^{2}$ \\ ${ }^{1 *}$ Departmen of Economics, Postgraduate Program Universitas Negeri Medan \\ ${ }^{2}$ Faculty of Economics Univeritas Negeri Medan \\ Email: ashrimaulida@gmail.com
}

\begin{abstract}
Waste management can reduce negative impacts on the environment, even if garbage is properly managed has economic value that is promising. Recycling is one of the businesses on waste minimization at the source of generation such as the Household and the Market must be addressed in the Final Disposal. more effective. This study aims to determine the economic value for the garbage collector. Does this activity has to be developed prosfek? This research is also expected to assist the government in formulating policies, among others, (1) the alleviation of poverty; (2) to determine the characteristics of the waste; (3) to determine the value of the sale of inorganic waste; (4) the value of marketing margin recycling efforts. For that determined the variables expected to affect the economy of scavengers that radius trash pickup, work experience, gender and the mode of transport used scavengers. Primary data were collected from households, markets, scavengers, agents of small and large agents inorganic waste recycling business. Descriptive analysis methods include behavioral analysis, analysis of the characteristics of household rubbish, garbage value analysis of inorganic and margin analysis. Linear Regression analysis method (Ordinary Least Square) to see the effect of these variables on the path towards economic scavengers Household and Final Disposal. The results of this study indicate that the variable radius waste pick-up and work experience scavengers positive effect on the economic value of the landfill scavengers either on line or lines of Household. Trash aqua glass, waste paper HVS, copper and garbage bins clear glass bottle is a kind of inorganic waste which has a high sales value per kilogram. Household garbage Marketing paths more effectively and profitably than the path landfill. Household scavenger pathway is more prosperous than landfill scavengers path. Public awareness is still low in maintaining the environment. Development activities in the Garbage Bank program has prospects for poverty reduction.
\end{abstract}

Key words: Scavenger, Recycling, Trash Economic Value, Margin

\section{INTRODUCTION}

arbage is a crucial issue faced by people, not only in cities but also those living
in the suburbs. Recently, waste has become an increasingly complicated
problem, especially in metropolitan and big cities in Indonesia. Trash cases 
occurred in Jakarta, Bogor, Depok, Tangerang and Bekasi (Jabodetabek) and Bandung Raya, which in late 2005 and early 2006 were hit by a sea of garbage. The condition of the pile of garbage in the TPA that is not processed can cause waste disasters such as exploding and landslides which have claimed many victims.

Medan is one of the big cities in Indonesia. The government of Medan City (2015) explains that every day the city waste production in Medan reaches 1,725 tons and the waste transported is only 525 tons / day consisting of $48 \%$ organic waste and $52 \%$ inorganic waste. And the increase in waste generation reaches $2-4 \%$ every year, but unfortunately this increase is not followed by the availability of infrastructure and facilities for adequate waste so that the remaining waste that has not been transported spoils the beauty of the city.

If observed, the emergence of solid waste problems cannot be separated from the behavior of humans / communities as producers and managers of waste. So far, it is felt that people's understanding and awareness of cleanliness have not gone according to expectations. There are still many people who litter, even though trash cans are available. They also do not realize that waste has an economic value that can add value to the household economy if it is managed properly and diligently. The problem of waste is not only the responsibility of the government, but also the responsibility of the whole community in an effort to minimize the amount of waste it produces every day.

Waste generation which always increases every year also increases the volume of waste cumulatively, causing many problems to occur in landfills. Many factors influence urban waste generation. The government of Medan City (2013) explains the factors that influence waste generation, namely population, socio-economic conditions, and technological progress.

The population that continues to increase will further increase the amount of waste generation. The following is data on the population and waste generation in Medan in 2010-2015.

Table 1: Amount of waste generation based on the population of Medan City in 2010-2015

\begin{tabular}{|l|l|l|l|l|}
\hline Year & Total population & $\begin{array}{c}\text { Waste generation } \\
\text { (kg / person / } \\
\text { day) }\end{array}$ & $\begin{array}{l}\text { The total of waste } \\
\text { generation per } \\
\text { day (kg) }\end{array}$ & $\begin{array}{c}\text { The total of } \\
\text { waste } \\
\text { generation per } \\
\text { year (ton) }\end{array}$ \\
\hline 2010 & 2.097 .610 & 0,8 & 1.678 .088 & 612.502 \\
\hline 2011 & 2.117 .224 & 0,8 & 1.693 .779 & 618.229 \\
\hline 2012 & 2.122 .804 & 0,8 & 1.698 .243 & 619.859 \\
\hline 2013 & 2.123 .210 & 0,8 & 1.698 .568 & 619.977 \\
\hline 2014 & 2.191 .140 & 0,8 & 1.752 .912 & 639.813 \\
\hline 2015 & 2.210 .624 & 0,8 & 1.768 .499 & 645.502 \\
\hline
\end{tabular}

Source: BPS, processed data. 0.8 unit of waste generation of the big city (SNI-S- 04- 199303 in Medan City Government, 2013)

From the table above, it can be seen that in 2010 with a population of 2,097,610 people, the waste generation generated in that year was 1,678,088 kg / day and reached 
612,502 tons / year. And the amount of waste generation has increased in the following years. It reached $1,768,499 / \mathrm{kg} /$ day and reached 645,502 / ton / year with a population of 2,210,624 people in 2015. This table shows that population growth affects the amount of waste generation. Increasing the population in each region / city, the amount of waste produced by each household will increase. The trend of the increase in waste generation in Medan City along with the increase in population in the Medan City can be clearly seen in the following graph:

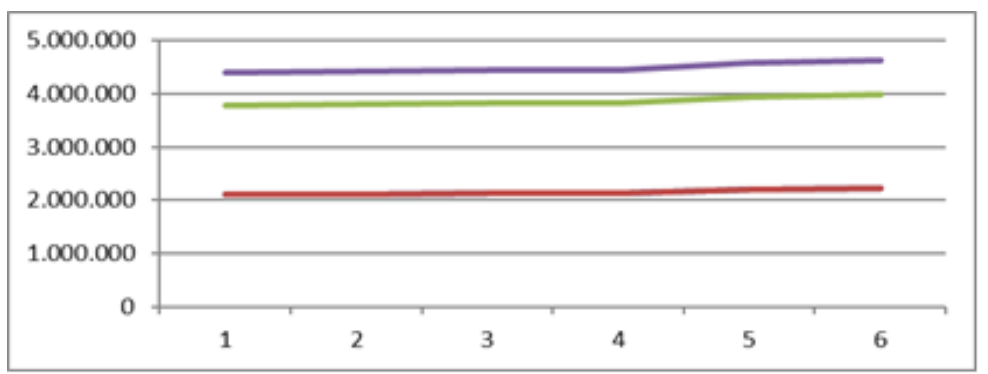

Figure 1: Graph of garbage growth per day and per year based on the population of Medan City

If the population in a city is large while the area is relatively small, then the garbage that is collected every day must be immediately collected, transported and disposed of so that it does not accumulate. If not, as a result, the entire city will become dirty, destroy the beauty of the city, cause a bad smell, and endanger public health because the pile of garbage becomes a nest for flies, rats and other animals. Not only the population, the socio-economic conditions of the community will also affect the amount of waste generation. The higher a person's socio-economic condition, the more waste generation they produce. People who have high incomes tend to choose an instant lifestyle. They prefer to buy food from restaurants and shop at supermarkets so that the waste generated is in the form of non-organic waste. The waste production rate will continue to increase. It is not only parallel to population growth but also in line with the increasing consumption patterns of society (Suyoto, 2008). One of the waste management activities in the waste minimization effort that has the advantage of economic value is recycling. Recycling activity is one of the techniques for processing solid waste into useful goods so that it can be reused, which consists of the stages of selecting, collecting, processing, distributing and manufacturing used materials, purchasing used materials. The process of recycling activities is carried out by the informal sector, namely scavengers and collectors of used goods (small and large) (Martinasari, 2009).

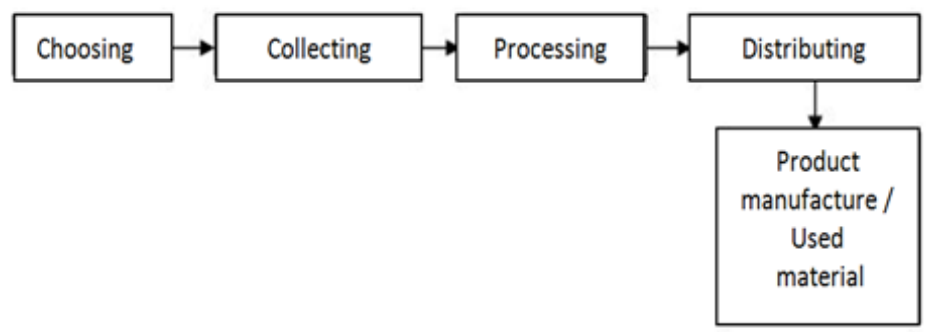

Figure 2: Recycling Activity Process

QE Journal | Vol.08 - No.01 - 3 
At the selection stage, waste is selected that has high economic value. At the collection stage, the selected waste is then collected at small or large collectors. Then the waste that has been collected by collectors is cleaned and grouped according to type and after that it is distributed to waste recycling factories as a basic material for making used product materials. This recycling activity can be applied by anyone, both individuals, households, agencies and also the government city. Rrecycling is also carried out formally and informally by urban waste recycling actors. The formal actors of urban waste recycling are steakholders who are given the authority by the city government to run and manage waste. And informal actors are scavengers, small stalls and large stalls who usually recycle waste with a certain economic value. (Peter J.M Nas and Rivke Jaffe in Andriyani and Maryono, 2010). The informal sector of waste recycling is a sector that carries out small scale recycling activities, whether carried out by individuals in the household or recycling businesses. This informal sector activity is also known as the "gray sector". This sector has an important role in economic growth (William in Andriyanti and Maryono, 2010)

In an economic aspect, waste recycling activities can reduce waste management operational costs, namely saving waste transportation costs. In general, the financing allocation for the solid waste sector is still below $5 \%$ of the total APBD. In addition, recycling also creates jobs in the informal sector such as scavengers and pelapak so that it can reduce unemployment (social aspect). Recycling activities among waste recycling actors (scavengers, small pelapak, and large pelapak) can be viewed as a relationship between systems that can be categorized as nodes, subpoints, and centerpoints (Sejati in Andriyani, 2009). An area for implementing waste recycling activities is said to be an open or closed area, where interactions occur between nodes, sub points, and center points. As a representation of the interaction and transfer of recycled waste between scavengers, small stalls and large lapak.

The characteristics of scavengers in carrying out waste sorting activities are divided into two, namely scavengers using mode and without mode. Scavengers who use this mode are divided into motorized (for example, garbage motorbikes, etc.) and non-motorized (using rickshaws, bicycles, etc.). Meanwhile, non-modal scavengers only rely on energy such as walking or pushing carts. The role of collectors is at the collection, processing and distribution stages. After the waste is sorted and collected by scavengers, the inorganic waste is packed and then deposited at the waste recycling plant. According to Poerwadarminta in Andriyani (2009), the definition of a stall is a place to collect used goods. Garbage is divided into two, namely large and small stalls. The small ones do not make it out to the recycling plant. Meanwhile, large lapak is a stall that directly distributes the collection of inorganic waste that has been received to the factory for manufacturing used products / materials.

Therefore, the utilization of the economic value of waste will be felt if it is done diligently. Someone who does work in one field for a long time, then he will tend to be good at doing that job. Of course this will also affect the economic value of the waste that will be obtained. The longer a scavenger is in his profession, the more he will know which waste has a high selling value and master the techniques. So that he is able to 
collect more waste to increase his income, work in an effective and efficient way and get more results. However, the amount of waste obtained between male and female scavengers tends to be different. This is because the factors of resistance and motivation are different between the two. This of course will affect the amount of waste obtained by both of them, so that the economic value of waste will be different between the two. In addition, the mode (transportation) used by scavengers to transport their waste will affect the amount of waste they can sell so that the mode will also affect the economic value of the waste they get.

\section{RESEARCH METHOD}

This type of research is descriptive qualitative and quantitative research. Where the author describes the subject or object observed in accordance with the data and information and facts obtained in the field during this research. Descriptive analysis methods include behavior analysis, household solid waste characteristics analysis, inorganic waste value analysis and margin analysis. Multiple Linear Regression (Ordinary Least Square) analysis method to see the effect of these variables on the economy of scavengers on the household route and the Final Disposal.

This research will be conducted in Terjun Urban Village, Medan Marelan Sub-District. In order to make it easier to understand the location which is the study area of each research object, it can be seen from the following table:

Table 2: The location of research

\begin{tabular}{|l|l|}
\hline \multicolumn{1}{|c|}{ Population } & \multicolumn{1}{c|}{ The location of research } \\
\hline Household & Around the Final Disposal area, Terjun Urban Village \\
\hline Market & Deli market in Rengas Pulau Village (close to the Final Disposal) \\
\hline Final Disposal & In Terjun Urban Village \\
\hline Little Agent & $\begin{array}{l}\text { - Scavengers who choose waste at the Final Disposal of Terjun Urban Village } \\
\text { - Scavengers who buy trash directly from Neighbourhood } \\
\text { - Small collectors who open used goods businesses around the Final Disposal of Terjun } \\
\text { Urban Village }\end{array}$ \\
\hline Big Agent & $\begin{array}{l}\text { 5 major agents in Medan Marelan Sub-district. Namely in Rengas Pulau Village (Kebun } \\
\text { Bunder, Titipapan) and in Terjun Urban Village (Andansari, Psr 4, Sungai Bederak). }\end{array}$ \\
\hline
\end{tabular}

The data used in this study are primary data obtained by questionnaires and secondary data. Data sources can be seen in table 3 below:

Table 3: Types and sources of data required

\begin{tabular}{|l|l|l|}
\hline \multicolumn{1}{|c|}{ Variable } & \multicolumn{1}{|c|}{ Type of data } & \multicolumn{1}{c|}{ Data source } \\
\hline Garbage collection radius & Primary data & $\begin{array}{l}\text { Scavengers from Neighbourhood } \\
\text { and Scavengers in Final Disposal }\end{array}$ \\
\hline Work experience & Primary data & $\begin{array}{l}\text { Scavengers from Neighbourhood } \\
\text { and Scavengers in Final Disposal }\end{array}$ \\
\hline Gender & Primary data & $\begin{array}{l}\text { Scavengers from Neighbourhood } \\
\text { and Scavengers in Final Disposal }\end{array}$ \\
\hline Mode (transport) & Primary data & $\begin{array}{l}\text { Scavengers from Neighbourhood } \\
\text { and Scavengers in Final Disposal }\end{array}$ \\
\hline
\end{tabular}




\begin{tabular}{|l|l|l|}
\hline $\begin{array}{l}\text { The economic value of waste (volume x } \\
\text { price of waste) }\end{array}$ & Primary data & $\begin{array}{l}\text { Scavengers from Neighbourhood, } \\
\text { Scavengers in Final Disposal, little } \\
\text { collectors,big collectors }\end{array}$ \\
\hline $\begin{array}{l}\text { Neighbourhood } \\
\text { patterns,market }\end{array}$ & behavior & Primary data \\
\hline $\begin{array}{l}\text { Neighbourhood behavior patterns, } \\
\text { scavengers }\end{array}$ & Primary data & $\begin{array}{l}\text { Scavengers from Neighbourhood } \\
\text { and Scavengers in Final Disposal }\end{array}$ \\
\hline
\end{tabular}

The population in this study were recycling business actors, namely scavengers, small agents, large agents and factories, as well as Neighbourhood and markets as sources of waste to be studied.

Table 4: Total population of research

\begin{tabular}{|l|l|}
\hline \multicolumn{1}{|c|}{ Population } & \multicolumn{1}{c|}{ Total population } \\
\hline Household & 7.620 Household \\
\hline Market & 200 sellers \\
\hline Final Disposal & 1 Final Disposal \\
\hline & $-\mathrm{n}$ scavengers in the final disposal \\
Little Agent & $-\mathrm{n}$ scavengers who buy garbage from Neighbourhood \\
& -8 little collectors \\
\hline Big Agent & 5 big collectors \\
\hline
\end{tabular}

Researchers took samples with the following characteristics: low Neighbourhood who live in Terjun Urban Village, market traders selling inside the market, scavengers who collect garbage at the Final Disposal, scavengers who buy garbage directly from Neighbourhood. Then the number of samples in this study are:

Table 5: Sample Total

\begin{tabular}{|l|l|}
\hline \multicolumn{1}{|c|}{ Population } & \multicolumn{1}{c|}{ Sample Total } \\
\hline Neighbourhood & 30 \\
\hline Marjet & 20 \\
\hline Scavengers from Neighbourhood & 35 \\
\hline Scavengers in Final Disposal & 35 \\
\hline
\end{tabular}

\section{RESULT AND DISCUSSION}

\section{Neighbourhood Behavior Analysis}

Table 6: Neighbourhood Knowledge and Attitudes Toward Solid Waste Collection Indicators

\begin{tabular}{|l|l|l|}
\hline \multirow{2}{*}{ Neighbourhood Knowledge Toward Solid Waste Collection } & \multicolumn{2}{c|}{ Respondent's answer (\%) } \\
\cline { 2 - 3 } & \multicolumn{2}{c|}{ Yes } \\
\hline Knowledge that garbage can create pollution & 100 & 0 \\
\hline Knowledge that waste can damage the environment & 100 & 0 \\
\hline The knowledge that trash can smell bad & 100 & 0 \\
\hline Knowledge that waste can cause disease & 100 & 0 \\
\hline The knowledge that trash should not be left scattered & 100 & 0 \\
\hline Knowledge that trash needs to be collected in one place & 100 & 0 \\
\hline Knowledge that waste has economic value & 83 & 17 \\
\hline
\end{tabular}


From the table above, it can be seen that Neighbourhood knowledge of waste is very good. Judging from the table above, Neighbourhood knows that the garbage can create pollution, can damage, smell bad, cause disease, need to be collected somewhere and should not be left scattered. However, for the knowledge that waste has economic value, there are $83 \%$ who know about it, $17 \%$ admit that they don't know that waste has economic value.

Table 7: Neighbourhood Knowledge and Attitudes Toward Waste Separation Indicators

\begin{tabular}{|l|l|l|}
\hline \multirow{2}{*}{ Neighbourhood Knowledge and Attitudes Toward Waste Separation } & \multicolumn{2}{|c|}{ Respondent's answer (\%) } \\
\cline { 2 - 3 } & \multicolumn{1}{|c|}{ Yes } & No \\
\hline Knowledge that waste consists of several types & 90 & 10 \\
\hline Knowledge that food waste is called organic waste & 70 & 30 \\
\hline $\begin{array}{l}\text { Knowledge that plastic, paper, glass and metal waste is called inorganic } \\
\text { waste }\end{array}$ & 77 & 23 \\
\hline $\begin{array}{l}\text { Knowledge that organic waste needs to be separated from inorganic } \\
\text { waste }\end{array}$ & 87 & 13 \\
\hline Knowledge that organic waste can be made into compost & 87 & 13 \\
\hline Knowledge that inorganic waste can be recycled & 90 & 10 \\
\hline
\end{tabular}

The table above deals with the separation of types of waste. As a result, Neighbourhood knows that the waste is divided into types, such as food scraps, plastic waste, paper, glass. Neighbourhood also knows that food waste includes organic and plastic, glass, metal and inorganic waste.

Table 8: Neighbourhood Knowledge and Attitudes Toward Waste Burning Indicators

\begin{tabular}{|l|l|l|}
\hline \multirow{2}{*}{ Neighbourhood Knowledge and Attitudes Toward Waste Burning } & \multicolumn{2}{|c|}{ Respondent's answer (\%) } \\
\cline { 2 - 3 } & \multicolumn{1}{|c|}{ Yes } & \multicolumn{2}{|c|}{ No } \\
\hline Knowledge that waste can be managed by burning it & 93 & 7 \\
\hline Knowledge that burning garbage can disturb the environment & 93 & 27 \\
\hline $\begin{array}{l}\text { The knowledge that burning means managing without taking } \\
\text { advantage }\end{array}$ & 73 & 47 \\
\hline Knowledge that combustion is safest in incenators & 53 & 57 \\
\hline Knowledge that burning garbage is prohibited & 43 & \\
\hline
\end{tabular}

From table 8 above, Neighbourhood knows that garbage can be managed by burning, and they do this often. By burning their garbage also damaging the environment, the smoke disturbs the surrounding environment. Some of them manage their waste by collecting it and throwing it into TPS (Temporary Disposal Site) around the house. Burning garbage means managing it without taking advantage, this was realized by Neighbourhood. However, as a result of further discussion, they have no choice but to manage by burning because by doing so they can completely destroy the waste, even 
though without realizing it, the effect of burning waste is wasteful of fuel, causes pollution, and destroys ozone.

Table 9: Neighbourhood Knowledge and Attitudes Toward Garbage Landfill Indicators

\begin{tabular}{|c|c|c|}
\hline \multirow[t]{2}{*}{ Neighbourhood Knowledge of Garbage Landfill Indicators } & \multicolumn{2}{|c|}{$\begin{array}{c}\text { Respondent's } \\
\text { answer (\%) }\end{array}$} \\
\hline & Yes & No \\
\hline Knowledge that waste can be managed by landfilling & 77 & 23 \\
\hline The knowledge that burying is put in a low position and covered by the soil returns & 73 & 27 \\
\hline The knowledge that burying trash has many benefits & 73 & 27 \\
\hline Knowledge that the land around the embankment can be more fertile than before & 93 & 7 \\
\hline Knowledge that plastic, metal, glass waste cannot be stockpiled & 50 & 50 \\
\hline
\end{tabular}

Hoarding is another way of managing waste. Neighbourhood knows that waste can be managed by backfilling by burying and then backfilling it and this can be done several times in the same hole.

Table 10: Neighbourhood Actions Against Waste Management

\begin{tabular}{|c|c|c|c|}
\hline \multirow[t]{2}{*}{ Indicator } & \multirow[t]{2}{*}{ Neighbourhood Waste Management } & \multicolumn{2}{|c|}{$\begin{array}{c}\text { Respondent's answer } \\
(\%)\end{array}$} \\
\hline & & Yes & No \\
\hline \multirow[t]{3}{*}{ Collection } & Provide trash bins around the house & 100 & 0 \\
\hline & Throw garbage in its place & 100 & 0 \\
\hline & Do not litter in any place & 20 & 80 \\
\hline \multirow[t]{2}{*}{ Separation } & Separating organic waste and inorganic waste & 47 & 53 \\
\hline & Provide a special trash can for each type of waste & 43 & 57 \\
\hline \multirow[t]{2}{*}{ Burning } & Burn the garbage that has been collected & 87 & 13 \\
\hline & Time period for burning waste & $\begin{array}{l}0 \times 1 \\
1 \times 1 \\
2 \times 1 \\
3 \times 1 \\
4 \times 1\end{array}$ & $\begin{array}{l}2=7 \% \\
4=13 \% \\
9=30 \% \\
9=30 \% \\
6=20 \%\end{array}$ \\
\hline Hoarding & Always carry out landfills & 17 & 83 \\
\hline
\end{tabular}

From the table above, for the action in the garbage collection indicator, Neighbourhood collects the garbage in the trash and does not let it scatter. However, in other places, some Neighbourhood still practice littering. For the indicators of separation, several RTs have separated waste based on its types and have provided special bins based on the type of waste. They separate wet trash from dry trash. Another Neighbourhood only uses 1 trash can for all types of waste. But from separating the trash cans, it still ends up mixing in their trash cans in their backyard.

\section{Market Behavior Analysis}

From the traders who sell in the market, we can see how the behavior of the traders in managing their waste. In the service indicator of the market cleaning program, the 
merchant explains that the market manager does not provide trash cans per trading stall, trash cans only exist at certain points in the market. There has never been any guidance or counseling by market managers regarding market cleanliness. The traders further explained that so far market cleaning has only relied on market cleaners, which only consists of 2 people (for areas within the market) who are in charge of cleaning the entire market area and all market waste is collected at a certain point to be transported by Final Disposal officers. For the transportation of garbage that has been collected at one point, this task is then carried out by the Sanitation Service officers who transport it with a frequency of $1 x$ every day at 2 p.m with 2-4 officers from the Cleaning Service. In the traders' participation in market hygiene, traders do not know the market hygiene program, and also the success rate. They explained that there was no coordination between traders and market managers, so there was never a meeting between traders and market managers to discuss the market cleaning program.

\section{Analysis of the Neighbourhood Scavenger}

The analysis of Neighbourhood scavengers is carried out to describe the welfare of neighbourhood scavenger, both RT scavengers and final disposal scavengers. This analysis is carried out by looking at the economic conditions of the household scavengers in terms of income and expenses. Household scavenger behavior is analyzed from the level of income, income per capita, expenditure and savings that he does in one month based on the level of age, education, radius, and his relationship with the agent. Age, education level, radius, and relationship with scavenger agents affect their income. In terms of income, the income received by Neighbourhood scavengers is on average greater than that of final disposal scavengers. This is because neighbourhood scavengers use a larger mode (transportation) to transport garbage and the radius they travel to collect waste is also further away and sells the garbage they collect collectively, namely by collecting garbage every day which they get and especially at home. Garbage that has been collected at home receives treatment from other family members by cleaning and regrouping according to its type, so that neighbourhood scavenger can sell their waste more and more expensive than final disposal scavengers because the waste they have collected is treated so that its economic value increases. This causes neighbourhood scavenger to have a higher average income than final disposal scavengers who only collect garbage in the morning and sell their garbage in the afternoon. So from the results of the above analysis, it can be concluded that the scavenger neighbourhood scavenger that collect garbage in the neighbourhood are more prosperous than the Neighbourhood scavenger. This is because their average income and per capita income are higher than that of final disposal scavengers. However, for the average saving, final disposal scavengers have a greater chance than neighbourhood scavenger to save from their remaining income after deducting expenses. Even though in reality it is difficult for each of them to set aside their income because of their unstable income and the increasing price of necessities. 


\section{The Analysis of the Characteristics of Household Waste that Has a Selling Value}

In general, many of neighbourhood do not want to use more than the leftovers of their neighbourhood. neighbourhood just buy and throw away items that have not been used because they are damaged, or even used goods sitting in the corner of the house become mosquito breeding grounds which can cause even more problems. One solution is to collect them and sell them to neighbourhood scavengers operating around your house. This relationship will be mutually beneficial, the neighbourhood will get economic value from its RT waste, and the scavengers will get recycled items to sell back to the agent. The following is a list of used goods that can be sold to RT scavengers along with the selling price / $\mathrm{kg}$

\section{Analysis of Inorganic Waste Value}

The Final Disposal of Terjun Urban Village is one of the two landfills owned by Medan City, but now it only operates alone because the Final Disposal of Namo Bintang has been closed since 2013. Of course, there will be a lot of waste coming in considering that Medan City continues to experience population growth, as well as activities. its economy is growing quite rapidly lately.

Table 11: Selling Price of Inorganic Waste 2014-2016 at Big Agent Level (in Rupiah)

\begin{tabular}{|l|l|l|l|l|}
\hline \multirow{2}{*}{ No. } & \multirow{2}{*}{ Types of Trash } & \multicolumn{2}{|c|}{ Year } \\
\cline { 3 - 5 } & & \multicolumn{1}{|c|}{$\mathbf{2 0 1 4}$} & \multicolumn{1}{|c|}{$\mathbf{2 0 1 5}$} & \multicolumn{1}{|c|}{$\mathbf{2 0 1 6}$} \\
\hline 1. & Plastic waste & 11.600 & 10.000 & 10.500 \\
\hline 2. & Metal waste & 81.000 & 73.000 & 55.500 \\
\hline 3. & Paper waste & 1.900 & 2.100 & 2.200 \\
\hline 4. & Glass waste & 700 & 800 & 700 \\
\hline
\end{tabular}

Source: Mixed Big Agent

From the table above, it can be seen that the price of waste continues to decline, but for paper waste the selling price has increased, although not too big. This is due to the market mechanism. The factory is the party that determines the selling price of waste because the recycled products they produce come into direct contact with the market. The factory is the agency that sets the price, the price of recycled waste depends on the demand for recycled waste as the basic material for making recycled goods. The price fluctuation can be seen in the chart below.

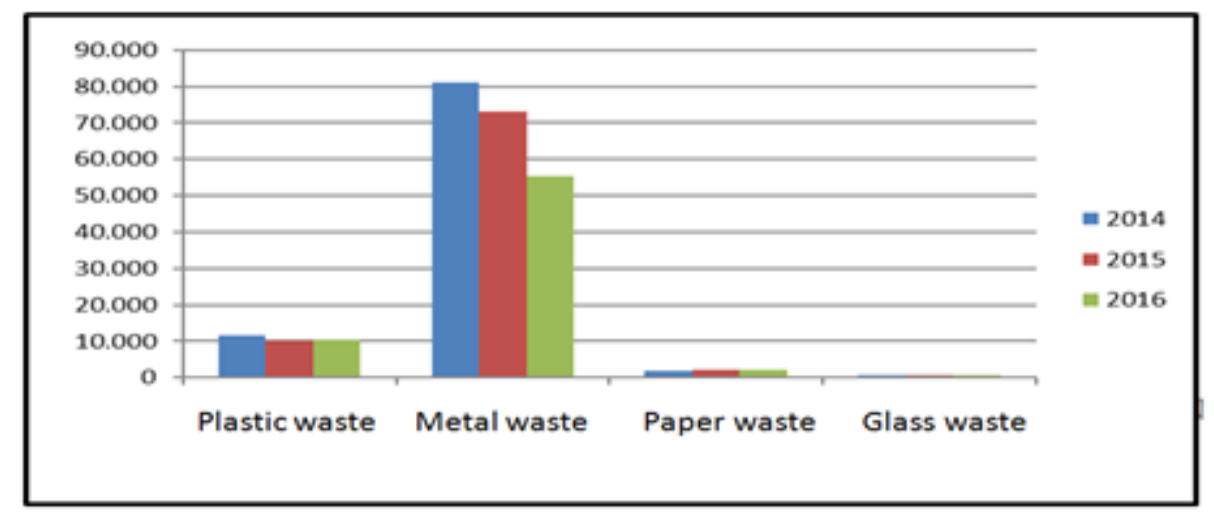

Figure 3: Selling Price of Inorganic Waste at Large Agent Level

QE Journal | Vol.08 - No.01 - 10 
The graph above shows the fluctuation in the selling price of inorganic waste at the level of large agents, namely the highest purchase price of waste made by factories to large agents. The price of metal tends to continue to decline, but for paper waste, it tends to increase, even though the increase is not too large.

The price of waste at various levels of distribution also experiences differences, from the scavenger to the factory level. This is because at each level of distribution, the waste undergoes treatment which in turn adds to its selling value at the next distribution level. The price difference can be seen in the following table:

Table 12: List of Purchase Price (PP) and Selling Price (SP) of Inorganic Waste from Scavenger-Factory Level (in Thousands of Rupiah)

\begin{tabular}{|c|c|c|c|c|c|c|c|c|c|c|}
\hline \multirow[t]{2}{*}{ Types of Trash } & \multicolumn{2}{|c|}{$\begin{array}{c}\text { Final } \\
\text { Disposal } \\
\text { Scavengers }\end{array}$} & \multicolumn{2}{|c|}{$\begin{array}{l}\text { Neighbourhood } \\
\text { Scavengers }\end{array}$} & \multicolumn{2}{|c|}{$\begin{array}{l}\text { Little } \\
\text { Agent }\end{array}$} & \multicolumn{2}{|c|}{ Big Agent } & \multicolumn{2}{|c|}{ Factory } \\
\hline & PP & SP & PP & SP & PP & SP & PP & SP & PP & SP \\
\hline Plastic waste & 0 & 2 & 2 & 4,5 & 4,5 & 5 & 5 & 10,5 & 10,5 & - \\
\hline Metal waste & 0 & 40 & 40 & 45 & 45 & 50 & 50 & 55 & 55 & - \\
\hline Paper waste & 0 & 1 & 1 & 1,7 & 1.3 & 1,7 & 1.5 & 2.5 & 2.5 & - \\
\hline Glass waste & 0 & 0,5 & 0,5 & 0,7 & 0,2 & 0,3 & 0,35 & 0,7 & 1,1 & - \\
\hline
\end{tabular}

Source: results of observations at various levels of distribution (processed data)

The purchase price at the Final Disposal Scavengers is "Rp. 0 "because they do not need to spend capital to buy the waste, they are free to collect as much garbage as possible at Final Disposal of Terjun Urban Village while the selling price at the factory level is not stated, because the factory is no longer selling in the form of waste, but rather a new product whose basic ingredients are mixed with waste products that can be managed again.

\section{Margin Analysis}

The margin analysis on the value of waste in Terjun Urban Village shows a quite large number. Margin analysis consists of two analyzes, namely the Marketing Margin (MM) and Profit Margin (PM) analysis on Neighbourhood and Final Disposal lines. In Neighbourhood route, the average value of MM was Rp. 15,475, - with a value, while the average Final Disposal value of MM reaches Rp. 17,275. and the average value of PM on the RT path reaches Rp. 15,225, - and Final Disposal route reaches Rp. 17.025, -. In the Margin analysis, it can be seen how much effective recycled waste marketing is. The greater the value indicates the ineffective recycling of the marketing chain for recycled waste between its distribution. And conversely, the smaller the margin value, the more effective the marketing chain between the distribution chains. The Profit Margin on the Neighbourhood line is smaller than the Profit Margin on the Final Disposal route because at Neighbourhood scavenger level, Neighbourhood scavengers have made selection and grouping and cleaning of the waste they collect so that at the Neighbourhood scavenger level the selling value of waste becomes higher because of the treatment they provide against the waste that will be sold. 


\section{Discussion of Test Results and Research Variables on Neighbourhood}

In the regression analysis on the RT path, from the results of the research and analysis that has been carried out it is concluded that all independent variables, namely radius (X1), work experience (X2), gender (X3) and mode (X4) of scavengers on the RT route simultaneously (together -sama) has a positive and significant effect on the economic value of Neighbourhood waste. However, partially, radius (X1) and work experience of scavengers (X2) on the Neighbourhood route have a positive and significant effect on the economic value of the Neighbourhood route waste, while gender (X3) and mode (X4) for the RT lane scavenger have no significant effect on the economic value of Neighbourhood lane waste. .

This result contradicts the research of Andriyanti and Maryono (2010) which states that the linear relationship of radius and mode of scavenger to the selling value of large mixed stalls is negative. And also contrary to Andriyanti's research (2009) which states that the relationship between radius and the selling value of scavengers to small collectors is not always positive.

The results of the analysis and partial testing of the Neighbourhood path, for testing the first hypothesis, obtained a regression coefficient value of 1.414586 and a t-count value of 2.794213 and a probability value of 0.0090 . Because the probability value is 0.0090 $<0.05$, then accept $\mathrm{Ha}_{1}$ or reject $\mathrm{Ho}_{1}$, which means that the first hypothesis is accepted and statistically verified at the level of $\alpha=0.05$, so it is concluded that the radius variable partially has a significant effect on the economic value of Neighbourhood route waste. The elasticity coefficient value of $1.4 \%$ indicates that the economic value elasticity of Neighbourhood route waste is elastic (the increase is elastic) to the radius of Neighbourhood route scavenger. This indicates that if the radius of Neighbourhood lane scavenger increases by 1 percent, the economic value of the RT route waste will increase by $1.4 \%$.

For testing the second hypothesis, the regression coefficient value is 0.520701 and the $\mathrm{t}$-count value is 1.939445 and a probability value is 0.0619 . Because the probability value is $0.0619<0.10$, then accept $\mathrm{Ha}_{2}$ or reject $\mathrm{Ho}_{2}$, which means that the second hypothesis is accepted and statistically verified at the level $\alpha=0.10$, so it is concluded that the Neighbourhood scavenger work experience variable partially has a significant effect on the economic value of lane waste Neighbourhood. The value of the elasticity coefficient of $0.5 \%$ indicates that the economic value elasticity of Neighbourhood route waste is inelastic to the work experience of Neighbourhood route scavenger. This gives an indication that if the work experience of Neighbourhood scavengers has increased by 1 percent, the economic value of Neighbourhood waste pathways will increase by $0.5 \%$.

To test the third hypothesis, the regression coefficient value is 3.482269 and the t-count value is 1.578593 and the probability value is 0.1249 . Because the probability value $0.1249>0.05$ then accept $\mathrm{Ho}_{3}$ or reject $\mathrm{Ha}_{3}$, which means that the third hypothesis is rejected and statistically valid at the level $\alpha=0.05$, so it is concluded that the gender variable partially does not have a significant effect on the economic value of Neighbourhood lane waste. The elasticity coefficient value of $3.5 \%$ indicates that the 
elasticity of the economic value of Neighbourhood waste is elastic to the sex of Neighbourhood scavengers. This gives an indication that if the number of male scavengers increases by 1 percent, the economic value of household waste in the Neighbourhood will increase by $3.5 \%$.

To test the fourth hypothesis, the regression coefficient value is 2.705679 and the $t$ count value is 1.104442 and the probability value is 0.2782 . Because the probability value is $0.2782>0.05$, then accept $\mathrm{Ho}_{4}$ or reject $\mathrm{Ha}_{4}$, which means that the third hypothesis is rejected and statistically valid at the level of $\alpha=0.05$, so it is concluded that the modal variable partially does not have a significant effect on the economic value of Neighbourhood route waste. The elasticity coefficient value of $2.7 \%$ indicates that the economic value elasticity of the Neighbourhood route waste is elastic to the RT scavenger mode. This gives an indication that if the scavenger mode increases by 1 percent, the economic value of Neighbourhood lane waste will increase by $2.7 \%$.

Based on the results of estimation and partial testing, it shows that the elasticity that most influences the economic value of Neighbourhood route waste is the gender variable of the RT route scavenger with the elasticity coefficient of $3.5 \%$ followed by Neighbourhood scavenger mode with a regression coefficient of $2.7 \%$. and radius variable with regression coefficient value of $1.4 \%$ and work experience variable of Neighbourhood path scavenger with regression correlation value of $0.5 \%$. Thus it appears that gender will have a greater effect on the economic value of Neighbourhood lane waste.

The variables of gender and mode of household scavengers do not have a significant effect on the economic value of household scavengers. The sex of the Neighbourhood scavenger is related to the physicality of the scavenger that has been obtained since birth. Each gender has its own advantages. In this case the physical strength of the RT scavenger who is male is much different from that of the Neighbourhood scavenger who is female and the internal motivation of the male scavengers is stronger than the female.

Male scavengers from the Neighbourhood route are the head of the family who earn a living as a responsibility for their family, while the female scavengers from the Neighbourhood route scavenge to help their family's economy so this has implications for increasing the amount of waste collected and sold and has an effect on increasing the economic value of the waste they get in Neighbourhood line.

However, in the field, scavengers from Neighbourhood of Terjun Urban Village, Neighbourhood collecting activities are not individual jobs that can be differentiated from the sexes of men and women. Neighbourhood scavengers in Kelurahanatuh are family chores which are done together with family members. When the head of the family who scavenges to Neighbourhood is sick, other family members will immediately replace their duties, and the results of the garbage collected by Neighbourhood scavengers at home are done together with all family members to get a higher selling value of waste. 
The second factor that does not have a significant effect on the economic value of waste is the mode (transportation) used by Neighbourhood lane scavengers to carry their garbage. The mode (transportation) of Neighbourhood scavengers has an important role in the economic value of waste received by Neighbourhood scavengers. The mode factor used is an important thing to consider because the mode factor is a means of transportation used to transport the collected waste for sale and get the economic value of the waste from the sale of the waste they have collected. Therefore, the size of the mode (transportation) used by Neighbourhood scavengers will affect the size of the economic value they get from selling the samaph they collect using that mode.

However, in the field, the scavengers of Neighbourhood of Terjun Urban Village are also included in the traditional type of scavenger who uses simple tools and equipment such as bicycle rickshaws and motorized rickshaws so that the size and sophistication of the limited modes of use does not affect the economic value of Neighbourhood waste scavengers. As well as with the coverage of the research area that is not too broad, the variant of Neighbourhood scavenger mode is not found in the Terjun Urban Village so that it affects the research results.

The third factor that also affects the economic value of Neighbourhood lane waste is the radius of the Neighbourhood lane scavenger. Neighbourhood scavenger radius is the farthest Neighbourhood scavenger can travel from his house to the farthest distance where he collects garbage. Radius is one of the most important production factors in the effort to obtain the economic value of Neighbourhood waste lines, because the farther the distance traveled, the wider Neighbourhood scavenger work area so that more waste can be collected and the waste it sells will be more so that it affects economic value trash it will receive.

The fourth factor that also influences the economic value of Neighbourhood lane waste is the work experience of Neighbourhood route scavenger. The work experience of an Neighbourhood scavenger is how long he has been working as a scavenger. The work experience of an Neighbourhood scavenger is one of the most important production factors in the effort to obtain the economic value of Neighbourhood line waste, because the longer he works as a scavenger, the more proficient he will be in collecting types of waste that have a high selling value and are more adept in technical work so that he can collect and sell waste in large quantities and high selling value.

This will certainly affect the economic value of the waste it will receive. The more experienced he is as an Neighbourhood scavenger will have a positive impact on increasing the economic value of the waste he will get, and conversely the less work experience the Neighbourhood scavenger has will affect the economic value of the waste he will get.

Furthermore, in Neighbourhood path, the results of analysis and hypothesis testing simultaneously obtained a probability value of $0.000<0.50$ which means reject $\mathrm{H}_{0}$ or accept $\mathrm{H}_{\mathrm{a}}$, so it is concluded that all variables, namely radius (X1), work experience (X2), gender (X3) and mode (X4) on the RT line together or simultaneously have a positive and 
significant effect on the economic value of Neighbourhood lane waste at the 95 percent confidence level.

In the test results the coefficient of determination obtained R-square (R2) value of 0.939319 . This shows that $94 \%$ of the variation in the dependent variable in this case the economic value of Neighbourhood lane waste can be explained by the independent variables consisting of radius, work experience, gender and mode of scavenger of Neighbourhood route. Meanwhile, the remaining $6 \%$ is explained by other variables not included in this model.

Thus, the results of estimation and hypothesis testing on Neighbourhood route show that simultaneously the independent variables, namely radius, work experience, gender and mode of scavenger of Neighbourhood route significantly affect the economic value of Neighbourhood lane waste. And partially, the variable radius and work experience of the RT line scavenger have a significant effect on the economic value of Neighbourhood line waste scavenger and the gender and mode of Neighbourhood lane scavenger variable do not have a significant effect on the economic value of Neighbourhood route waste. This gives an indication that each additional radius and work experience of Neighbourhood scavengers will result in an increase in the economic value of waste that will be received by Neighbourhood line scavengers.

\section{CONCLUSIONS AND RECOMMENDATIONS}

1. The level of knowledge and attitude of Neighbourhood of Terjun Urban Village in general towards waste collection, separation, burning and landfilling is generally quite high, especially in the collection and separation of waste. However, the actions of Neighbourhood of Terjun Urban Village were not in accordance with the knowledge and attitudes they had. Burning is still their preferred method of handling their waste without taking more benefit from the rest of their Neighbourhood. This shows that the low awareness of Neighbourhood of Terjun Urban Village all towards the sustainability of its environment.

2. The level of knowledge of traders in Deli Market, Rengas Pulau Sub-district, on the market cleaning program is still very low, this has an impact on the indifference of traders to market cleanliness who only leave matters of market cleaning to market cleaners.

3. Neighbourhood scavengers who are young, have low education with a far radius of garbage collection and have a subscription relationship with permanent agents have Neighbourhood that are more prosperous than Final Disposal scavengers.

4. Some household items have a high selling value, including aqua glass waste for plastic waste, copper waste for metal waste, clear bottle waste for glass waste, white HVS paper waste for paper waste.

5. The average value of marketing margin and profit margin in Neighbourhood channel is lower than the average value of marketing margin and profit margin in Final Disposal route. Indicates that marketing on the Neighbourhood channel is more effective than marketing on Final Disposal channel. 
6. Simultaneously, radius, work experience and landfill route mode have a significant positive effect on the economic value of landfill waste.

7. Simultaneously radius, work experience, gender, and Neighbourhood lane mode have a significant positive effect on the economic value of Neighbourhood lane waste.

8. The regression results on Final Disposal pathway obtained the coefficient of determination (R2) of 0.974476 . This shows that $97 \%$ of the variables radius, work experience, gender and mode of Final Disposal route explain the economic value variables of Final Disposal waste. Meanwhile, the remaining 3\% is explained by other variables not included in this model.

9. The regression results on Neighbourhood path obtained the coefficient of determination (R2) of 0.939319 . This shows that $94 \%$ of the variables radius, work experience, gender and Neighbourhood route mode explain the economic value variables of Neighbourhood lane waste. Meanwhile, the remaining $6 \%$ is explained by other variables not included in this model.

10. Partially, Final Disposal route shows that each radius variable, work experience significantly affects the economic value of the waste from Final Disposal route, while mode does not have a significant effect on the economic value of landfill waste. The elasticity of the economic value of landfill waste is inelastic (the increase is inelastic) with respect to the radius, work experience and mode o Final Disposal route.

11. Partially, on Neighbourhood line it shows that each radius variable, work experience significantly affects the economic value of Neighbourhood line waste, while gender and mode do not have a significant effect on the economic value of Neighbourhood route waste. The elasticity of the economic value of Neighbourhood route waste is elastic (the increase is elastic) with respect to the radius, gender and mode of Neighbourhood route and is inelastic (the increase is inelastic) with respect to the work experience of Neighbourhood scavenger.

12. The elasticity that has the greatest influence on the economic value of landfill waste scavenger is the variable work experience of landfill scavenger with a regression coefficient of $0.7 \%$ and followed by a variable radius of landfill scavenger with a regression coefficient of $0.2 \%$. Thus, it appears that the work experience of landfill scavengers will have a greater effect on increasing the economic value of waste that will be received by landfill scavengers.

13. The elasticity that most affected the economic value of Neighbourhood lane waste was the variable radius of taking RT lane waste with an elasticity coefficient of $1.4 \%$ and was followed by a variable work experience of Neighbourhood lane scavengers with an elasticity coefficient of $0.5 \%$. Thus, it appears that the radius of taking the work of the Neighbourhood line will have a greater effect on the increase in the economic value of waste that will be received by Neighbourhood line scavengers. 


\section{REFERENCES}

Andriyanti, Riki. 2009. "Pemodelan Grafis Perilaku Daur Ulang Sampah di Lapak Besar Kelurahan Panggung Lor, Kuningan, dan Bandarharjo". Tugas akhir Jurusan Perencanaan Wilayah dan Kota Fakultas Teknik Universitas Diponegoro Semarang

Andriyani, Riki dan Maryono. 2010. "Interaksi Pelaku Daur Ulang Sampah Melalui Uji Regresi Linear di Kelurahan Panggung Lor, Kuningan dan Bandar Harjo Kota Semarang". Jurnal PRESIPITASI Vol. 7 No. 1 ISSN 1907-187X

Ardi, M, Abdul Hamid Aras, Syahradi, dan Yusuf Marsuku. 1992. “Dampak Pembangunan Jaringan Irigasi Terhadap Peningkatan Pendapatan Petani dan Efisiensi Penggunaan Faktor- Faktor Produksi di Provinsi Sulawesi Selatan", Hasil Penelitian Perguruan Tinggi, Departemen Pendidikan dan Kebudayaan Bogor.

BPS Sumatera Utara, Kependudukan. Luas wilayah, jumlah penduduk dan kepadatan penduduk menurut kabupaten/ kota 2012, 2013, 2014 dan 2015.

Djajadiningrat, Surna Tjahja dkk. 2011. “Ekonomi Hijau”. Bandung: Rekayasa Sains

Fauzi, Ahmad. 2010. "Ekonomi Sumber Daya Alam dan Lingkungan”. Cetakan Ketiga. Jakarta: PT. Ikrar Mandiriabadi

Fisher, R.C. 1996. "State and Local Public Finance". New York: Irwin.

Gujarati, Damodar. 2004. "Basic Econometrics". Edisi ke empat. New York: McGraw Hill. Gumbira, E dan Harizt Intan. 2001. "Manajemen Agribisnis", Jakarta: Ghalia Indonesia

Hidayat, Moch. Maulana. 2012. "Profil Pemulung Sampah TPA", Repository, Universitas Pendidikan Indonesia, Bandung.

Hyman, D.N. 1999. "Public Finance: A Contemporary Application of Theory to Policy". Sixth edition. , New York: The Drisden Press.

Mandailing, M. Muslim. 2001. "Partisipasi Pedagang dalam Program Kebersihan dan Pengelolaan Sampah Pasar." Tesis Program Pasca Sarjana IPB, Bogor.

Martinasari, Mona. 2009. "Pola Persebaran dan Jangkauan Pelayanan Pengepul Besar Dalam Kegiatan Daur Ulang Sampah Kota Semarang (studi kasus: kelurahan kuningan, panggung lor dan bandarharjo)". Tugas Akhir Jurusan Perencanaan Wilayah dan Kota Fakultas Teknik Universitas Diponegoro Semarang

Mas-Colell, A., Whinston, M.D., dan J.R Green. 1995. "Microeconomic Theory". Oxford: Oxford University Press.

Mishan,E.J. 1971."The Post-War Literaure on Externalities:An Interpretive Essay", Journal of Economic Literature, 9:1-28.

Morgan, Sally. 2009. "Daur Ulang Sampah". (Terj) Inik B. Utami Solo: PT. Tiga Serangkai Pustaka Mandiri 
Mukhlis, Imam. 2009. "Eksternalitas, Pertumbuhan Ekonomi, dan Pembangunan Berkelanjutan dalam Persfektif Teoritis". Jurnal Ekonomi Bisnis Tahun 14 No. 3 ISSN 0853- 7283

Oswari, Teddy dkk. 2006. "Potensi Nilai Ekonomi Pengelolaan Sampah Di Kota Medan". Jurnal Ekonomi dan Bisnis No. 2 Jilid 11

Pemerintah Kota Medan. 2013. "Kajian Model Pengelolaan sampah dan SDM Kebersihan di Kota Medan". Provinsi Sumatera Utara

Pemerintah Kota Medan. 2015. "Pelaksanaan Focused Group Discussion (FGD) Pengelolaan Sampah dengan Cara 3R Berbasis Masyarakat." Diakses tanggal 12 Juni 2016 pada halaman www.pemkomedan.go.id

Rahardyan B. Dan Widagdo A.S. 2005. "Peningkatan Pengelolaan Persampahan Perkotaan Melalui Pengembangan Daur Ulang. Materi Lokakarya 2 Pengelolaan Persampahan di Provinsi DKI Jakarta". Jakarta

Rahman, Haikal. 2012. "Valuasi ekonomi alternatif teknologi pengelolaan sampah perkotaan". QE Journal | Vol.01 - No.01-44

Riyanto, Bambang. 2008. "Prospek Pengolaan Sampah Non Konvensional di Kota Kecil (Studi kasus: Kecamatan Gunung Kidul)." Tesis Pasca Sarjana Magister Teknik Pembangunan Wilayah Universitas Diponegoro. Semarang.

Sepdian, Ana Afita. 2006. "Perilaku Masyarakat Dalam Mengelola Sampah". Skripsi Prodi Penyuluhan dan Komunikasi Pertanian, Fakultas Pertanian, IPB, Bogor.

Soekarwati. 2003. "Teori Ekonomi Produksi dengan Pokok Bahasan Analisis Fungsi Coub Douglas". Jakarta: Raja Grafindo

Soemarwoto, Otto. 2004. "Ekologi, Lingkungan Hidup dan Pembangunan". Edisi Kesepuluh, Jakarta: Djambatan

Standart Nasional Indonesia Nomor SNI-19-2454-2002 tentang Tata Cara Pengelolaan Sampah Perkotaan, Badan Standart Nasional (BSN)

Sudirman, B, 1989, "Efisiensi Penggunaan Faktor Produksi dalam Usaha Tani di Kabupaten Sindereng Rappang: pendekatan ekonometri". Tesis

Sugiyono. 2008. "Metode Penelitian dan Pendidikan". Bandung: CV. Alfabeta.

Suharno, B dan Nazaruddin, 2006, "Ternak Komersial", penerbit Swadaya, jakarta.

Surjandari, Isti dkk. 2009. "Model Dinamis Pengelolaan Sampah Untuk Mengurangi Beban Penumpukan". Jurnal Teknik Industri Vol. 11 No. 2 pp. 134- 147 ISSN 14112485

Suyoto. 2008. "Rumah Tangga Peduli Lingkungan". Cetakan Pertama. Jakarta: PT. Prima Infosarana Media 